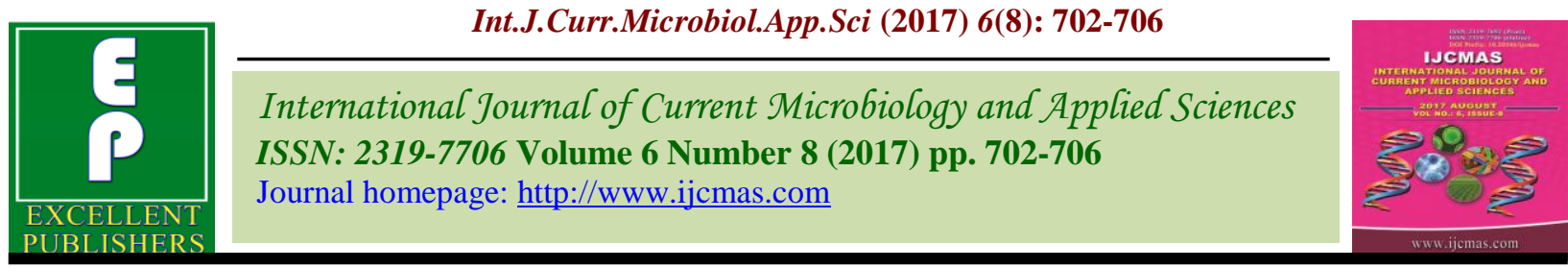

Original Research Article

https://doi.org/10.20546/ijcmas.2017.608.089

\title{
Atypical Occurrence of Pearls Tuberculosis in a Cow-Pathomorphological Findings
}

\author{
K.M. Palanivel ${ }^{1}$, A.P. Surendar ${ }^{1 *}$ and P. Kanimozhi ${ }^{2}$ \\ ${ }^{1}$ Department of Veterinary Epidemiology and Preventive Medicine, Veterinary College and \\ Research Institute, Namakkal, India \\ ${ }^{2}$ Tamilnadu Veterinary and Animal Sciences University, Tamilnadu, Chennai, India \\ *Corresponding author
}

\section{A B S T R A C T}

\begin{tabular}{|c|c|}
\hline Keywords & $\begin{array}{l}\text { Bovine tuberculosis (BT) is an infectious disease of cattle and one of the biggest } \\
\text { challenges facing the colossal economic loss in cattle farms particularly in developing }\end{array}$ \\
\hline $\begin{array}{l}\text { Bovine } \\
\text { tuberculosis, } \\
\text { Pearl's nodules, } \\
\text { Acid fast bacilli, } \\
\text { Zoonoses. }\end{array}$ & $\begin{array}{l}\text { countries and also causing public health significance. Mortality reported due to pearl's } \\
\text { tuberculosis and sub acute enteritis among adult cattle and young calves at Livestock } \\
\text { Research Station, Kattuppakkam, Tamilnadu, India with good farm biosecurity measures } \\
\text { and located in the semi-arid tropical region have been analysed. } 1(14.3 \%), 3(42.9 \%) \text { and } \\
1(14.3 \%) \text { died due to tuberculosis, sub acute enteritis and pneumonia respectively between }\end{array}$ \\
\hline Article Info & $\begin{array}{l}\text { May } 2008 \text { to December } 2010 \text {. There is no specitic cause of death } 2(28.6 \%) \text { in adult } \\
\text { animals. The postmortem lesions of plural adhesions, caseous and calcified tuberculos }\end{array}$ \\
\hline $\begin{array}{l}\text { Accepted: } \\
\text { 04 June } 2017 \\
\text { Available Online: } \\
10 \text { August } 2017\end{array}$ & $\begin{array}{l}\text { nodules in the lungs and bunch of light yellow nodules similar to the arrangements of } \\
\text { whole maize grains over a cob on the ribs and diffuse inflammation, granules tissue } \\
\text { formation and connective tissue proliferation along with abundance of acid fast bacilli } \\
\text { were recorded. }\end{array}$ \\
\hline
\end{tabular}

\section{Introduction}

Bovine tuberculosis (BT) caused by Mycobacterium bovis (M. bovis) has no geographical boundaries and infections occurs in diverse group of animals which includes farm animals of economic importance, wild animals and humans (Pavlik et al., 2002). Zoonotic bovine TB is present in many developing countries where surveillance and control activities are often inadequate (Cosivi et al., 1998a). In India, nearly $70 \%$ of the population is dependent on the agriculture and rearing of livestock, contrary to less than $3 \%$ in many developed countries. Though India is the largest milk producers in the world i.e., about 112.5 million tons and also stands first in terms of milk cattle population with 175 million cattle (FAOSTAT, 2008), still milk production per animal is far below the developed countries (Hemme et al., 2003). Infectious diseases are one of the major reasons for the economic losses in the dairy sector, amongst them Bovine tuberculosis causes great economic losses and poses an enormous public health threat as well (O’Reilly and Daborn, 1995).

Tuberculosis is remains to be the highly infectious and the most important bacterial disease resulting in colossal economic losses (Palanivel et al., 2011), causing higher 
morbidity and mortality amongst animals as well as humans (OIE, 2008). The incidence of tuberculosis in India has been largely built up from two sources (a) Examination of carcass in the slaughter houses (b) Mass tuberculin testing in cities, villages and other various government and organized farms (Palanivel et al., 2011).

The present study is reported an occurrence of pearl's tuberculosis (PT) in a Jersey cross bred cow during post mortem examination.

\section{Case history and observation}

A six year old jersey cross bred cow maintained in the cattle farm of Livestock Research Station, Kattuppakkam was died suddenly and brought to the hospital section for post mortem examination. The farm having the history of maintaining multispecies (i.e., cattle, buffalos, sheep and goats, pigs and ostriches) and rare incidence of tuberculosis in cattle and pigs and in endemic for paratuberculosis in sheep, cattle and buffalos. But the animal died revealed nonreactor during routine screening (single intradermal tuberculin) test against tuberculosis and Johne's disease. The period from May 2008 to December 2010, a total of 7 postmortem of both adult (3) and young calf (4) were conducted at Livestock Research Station, Kattupakkam, Tamil Nadu. Amongst 3 milch animals, one animal were detected to have moderate caseous and calcified tuberculos lesion in the lungs and bunch of light yellow nodules looks similar to the arrangement of grains over a cob (whole maize structure) (Figs. 1, 2 and 3) on the ribs were removed and examine for cheese materials, typical characteristic reproducible microorganism of Acid Fast bacilli. There is no gross pathological lesion in the remaining animals as well as calves. Smears from nodules of cheese material, parietal membrane and parenchymatous organs were subjected to Ziehl-Neelsen staining technique. After the complete necropsy, tissue specimens were collected and fixed in $10 \%$ formalin for routine histopathological examination. The source of concentrate feed for these animals was received regularly from Poultry Research Station (PRS), Nandanam, Chennai-35. There is no major disease outbreak reported during this period in this farm.

\section{Results and Discussion}

The incidence of typical PT lesions of 14.3 percent in Jersey crossbred cow, 42.9 percent of sub acute enteritis and 14.3 percent of pneumonia in young calves recorded in this investigation was in agreement with Edwards (1927) and Palanivel et al., (2011) who reported that 16 percent and 2.8 percent to 5.6 percent of tuberculosis in animals at Kanpur and Tamilnadu respectively.

However, in this report lesions were usually typical, capsulated nodules approximately 0.5 to $2 \mathrm{~cm}$ in diameter with calcification (Fig. 3) in about 8 percent of lesions in this case. The adjoining lung parenchyma revealed peribronchial fibrosis and the atelectasis of alveoli. The mediastinal and bronchial lymph nodes were involved in 50 percent with adhesions to pleura. Granulomatous lesion containing large numbers of acid fast bacilli develop in lungs, mediastinal and sub-pleural lymph nodes. The latter have a pearl like appearance and this condition is termed as pearls nodules. Similar findings were also reported by Schaff and Zumala (2009). Concurrent with Pavlik et al., (2005); Chaugan et al.,(2005) and Sukhla and Singh (1972), the present study revealed a cluster of typical (yellow) closely placed tuberculos nodules under the shining, smooth serous surfaces (Figs. 1 and 2) had the typical tuberculos lesions and reproducible microorganisms of acid fast bacilli. 
Fig.1 Diffuse caseated tuberculos nodules in lungs

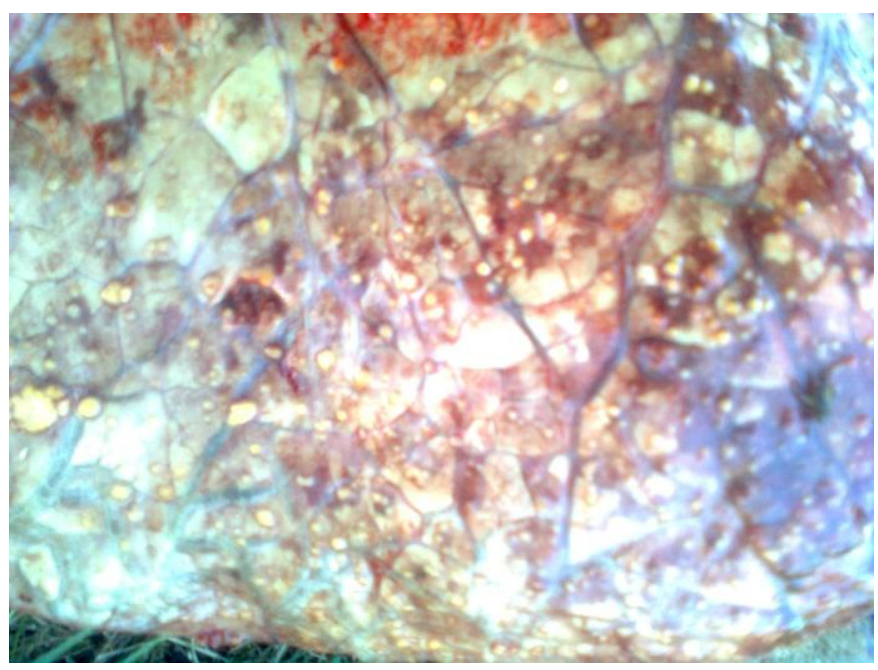

Fig.2 Showing light yellow nodules on rib (arrangements of whole maize grains over a cob)

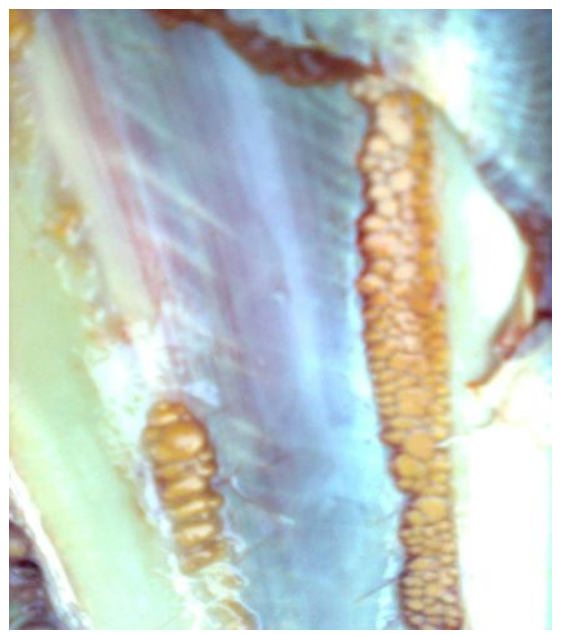

Fig.3 Showing typical, capsulated nodules approximately 0.5 to $2 \mathrm{~cm}$ in diameter with calcification

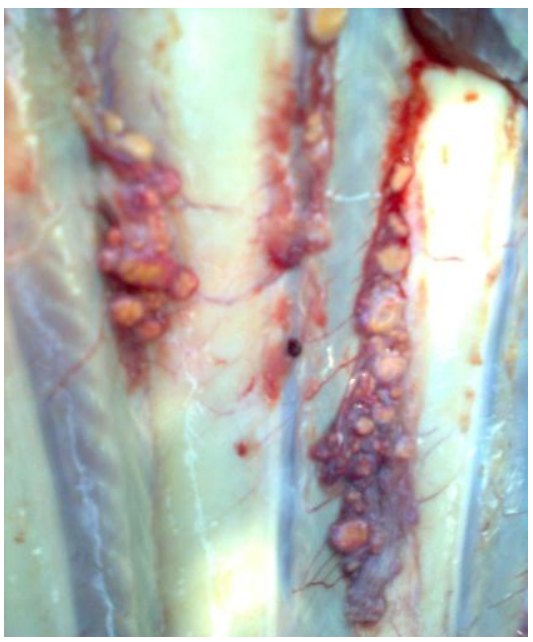


Fig.4 TB nodule showing caseation necrosis, epitheloid cells and giant cells H\&E x 400

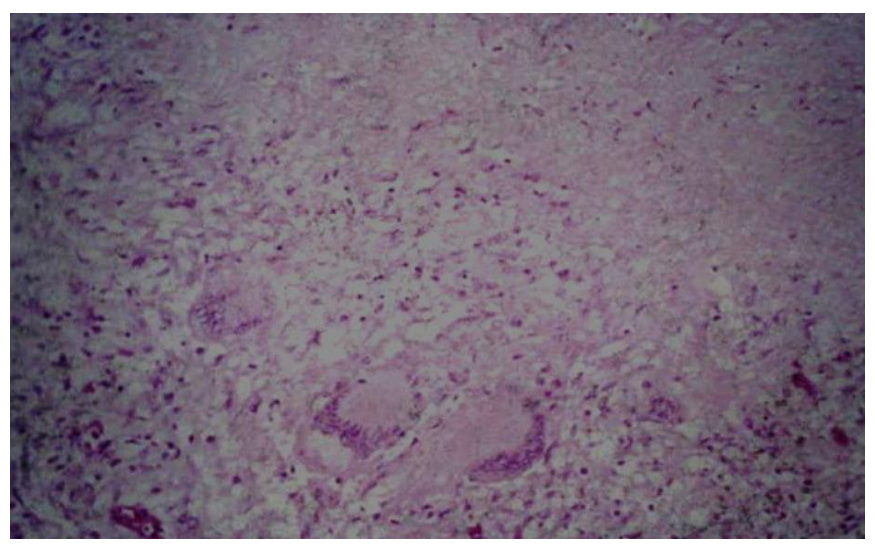

Fig.5 Impression smears from lungs of cow revealed numerous typical acid fast bacilli (pink rod shaped) within the epitheloid cells, Zeihl Neilson x 1000

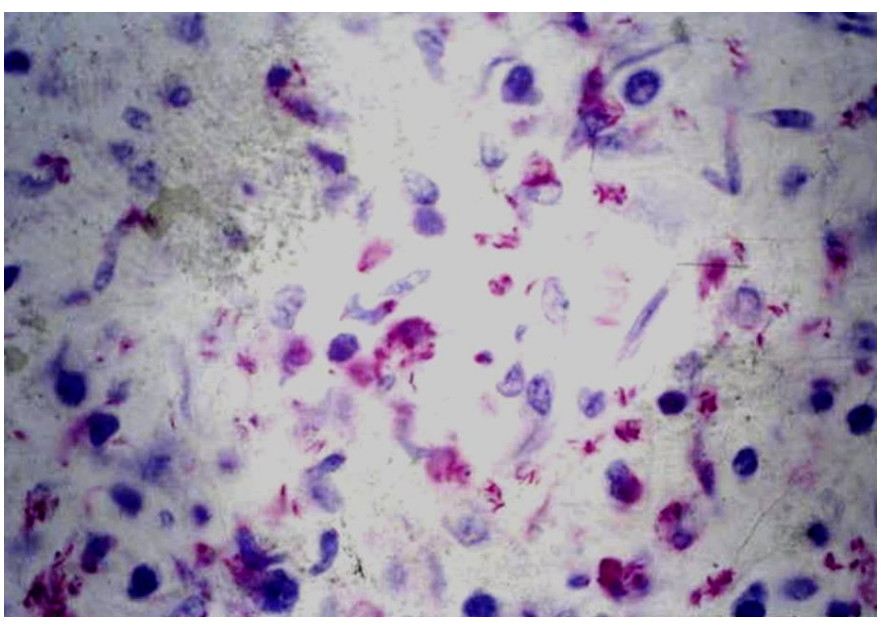

The most important observation in this study was the present case revealed non-reactor while regular Tuberculin screening tests during their life time. The reasons for the occurrence of pearls tuberculosis lesions in this animal due to different levels of infection in crossbred in individual countries and false negative results due to poor sensitivity of this single intradermal tuberculin tests make themselves felt differing contribution of Mycobacterium species which causes tuberculos lesion in this animal. In addition to the characteristic mortality amongst adult cow in this investigation, one of the features of Mycobacterium spp. and or opportunistic Mycobacteria was that it persists for long periods in adult cow without clinical signs. This can lead to excretion of organism via faeces, milk and perpetuation of infection in the shed, contamination of pastures, feed and water which can results to other susceptible animals in their herd mate (Palanivel et al., 2011; Cosivi et al., 1998b and Matlova et al., 2005). The observation of gross pathological lesions and reproduced the same morphological appearance of AF bacilli from the specimens in this study was well corroborated with the results of (Srivastava $e t$ al., 2008; Dwivedi and Singh, 1966 and Rathore and Singh, 1969). Histopathological changes of tissues (lungs and pleural membrane) revealed diffuse inflammation, 
granules tissue formation and connective tissue proliferation along with abundance of AF bacilli (Figs. 4 and 5). Similar findings reported by Schaff and Zumala (2009) and Palanivel et al., (2011).

\section{References}

Chauhan, D.S., Katoch, V.M., Dwivedi, S.S. and Kalra, D.S. 2005. Bovine tuberculosis in India: A zoonosis. Proceedings of National Academic Science India, 75B: 55-60.

Cosivi, O., Grange, J.M., and Daborn, C.J. 1998a. "Zoonotic tuberculosis due to Mycobacterium bovis in developing countries," Emerging Infect. Dis., 4: 1-17.

Cosivi, O., Grange, J.M., Daborn, C.J. and Raviglione, M.C. 1998b. Zoonotic tuberculosis due to Mycobacterium bovis in developing countries, Emerg. Infec. Dis., 4: 1-17.

Dwivedi, J.N. and Singh, C.M. 1966. Pulmonary tuberculosis in buffaloes. Indian Vet. J., 43: 582-588.

Edwards, J.T. 1927. Bovine tuberculosis in India, F.E.A.T.M Translation of the $7^{\text {th }}$ Congress, 11, 5988-602.

FAOSTAT. 2008. Production data, www.faostat.org. 133.

Hemme, J.M., Katoch, V.M. and Chauhan, D.S. 2003. A review of milk production in India with particular emphasis on small scale producers in Pro-poor livestock policy imitative (PPLPI) Working paper no. 2, FAO Animal Production and Health division, Rome, Italy, 1.

Matlova, L., Dvorska, L., Ayek, W.Y., Bartos, M., Amemori, T. and Pavlik, I. 2005. Bovine tuberculosis: an old disease but a new threat to Africa, Clin. Microb., 43: 1261-1268.

O'Reilly, L.M., and Daborn, C.J. 1995. The epidemiology of Mycobacterium bovis infection in animals and man- a review, Tubercle. Lung Dis., 76: 1-46.

OIE. 2008. Paris, Manual of standards for diagnostic tests and vaccines, Bovine Tuberculosis, 683-697.

Palanivel, K.M., Sureshkumar, K., Gopinathan, A. and Sivaselvam, S.N. 2011. Perspective study on Tuberculosis in pigs- Postmortem findings, Indian J. Anim. Res., 45: 310-313.

Pavlik, I., Bures, F., Janovsky, P., Pecinka, P., Bartos, M., Dvorska, L., Matlova, L., Kremer, K. and Soonlingen, D. 2002. Incidence of bovine tuberculosis in wild and domestic animals other than cattle in six central European countries during 19901999 Vet. Med., 47: 122-131.

Pavlik, I., Matlova, L., Dvorska, L., Shitaye, J.E. and Parmova, I. 2005. Bovine tuberculosis - epidemiological survey in dairy farms, Vet. Med., 50: 291-299.

Rathore, B.S., and Singh, N.P. 1969. Pulmonary tuberculosis in buffaloes a study on its incidence and pathology, Indian J. Animal Health, 8: 85-87.

Schaff, H.S. and Zumala, A. 2009. TuberculosisA comprehensive clinical reference, Saunders, Elsevier Publication Ltd, 242245.

Srivastava, K.S., Chauhan, D.S., Gupta, P.I., Singh, H.I., Sharma, V.D., Yadav, V.S., Sreekumaran, S.S., Thakral, J.S., Dharamdheeran, P., Nigam, P., Prasad, H.K. and Katoch, V.M. 2008. Isolation of Mycobacterium bovis and M. tuberculosis from cattle of some farms in North IndiaPossible prevalence in human health, Indian J. Med. Res., 128: 26-31.

Sukla, R.R. and Singh, G. 1972. Studies on tuberculosis amongst Indian buffaloes, Indian Vet. J., 49: 119-123.

\section{How to cite this article:}

Palanivel, K.M., A.P. Surendar and Kanimozhi, P. 2017. Atypical Occurrence of Pearls Tuberculosis in a Cow- Pathomorphological Findings. Int.J.Curr.Microbiol.App.Sci. 6(8): 702706. doi: https://doi.org/10.20546/ijcmas.2017.608.089 